\title{
Archival images and audiovisual testimony - Negotiating the end of empire in the documentary films Guerra Colonial. Histórias de Campanha em Moçambique (1998) and Natal 71 (1999) ${ }^{1}$
}

\section{ABSTRACT}

This article analyses Portuguese documentary films from the 1990s, when public discussions about the war of decolonization gained a new dynamic. The video series Guerra Colonial. Histórias de Campanha (Quirino Simões, 1998) relates the war in Angola, Guinea and Mozambique mainly by drawing on archival material and voice-over narration. Margarida Cardoso's Natal 71 (1999) concentrates on specific episodes and individual experiences of the war in Mozambique. This article explores

\section{KEYWORDS}

archive documentary film memory Mozambique Portugal 
1. This article is based on a paper presented at the VIII Congreso Ibérico de Estudios Africanos on 14-16 June 2012 in Madrid. how the aforementioned films use certain strategies to include footage, other visual representations and audiovisual testimonies in order to create a specific image of the past. The leading question is not how much truth these films contain, but rather which techniques they implement in order to produce truth, authenticity and evidence about the war and the people involved. I will argue that documentary productions constitute a form of memory politics in which discussion and negotiation of the colonial past are brought forward from particular social frameworks situated in the present.

\section{INTRODUCTION}

The struggle for independence led by different movements in the Portuguese colonies in the 1960 s coincided not only with the technical development of portable cameras and audio recording devices, but also with the emergence of new cinematic genres like Direct Cinema, Cinéma Vérité and Third Cinema, which challenged conventional forms of both fiction and documentary film (Müller 2011: 89-112; Willemen 1991). These circumstances also contributed to a certain extent to the filmic production initiated by the liberation fronts' in Angola, Guinea-Bissau and Mozambique, which invited film-makers from countries such as Cuba, Sweden, the United States and the United Kingdom (Chanan 1985: 236; Minter 2008; Convents 2011: 350; Dickinson 2011: 131). On the Portuguese side, the armed forces and the public television station Radio Televisão Portuguesa (RTP) were engaged in the production of moving images that propagated military victory and harmonious relationships between armed forces, settlers and African populations, as well as industrial and economic development (Cádima 1996; Mendonça 1993).

Such films have not been forgotten in the present time. Since the end of colonial rule, they have circulated in diverse forms and formats, for example, as parts of new documentary films and in film festivals. As extracts or in their full lengths, these films are appropriated and mobilized by different actors, and are thus subject to a number of readings that invest them with (often other) meanings. Recently, such material from colonial and anti-colonial archives, like many other audiovisual fragments, has entered the World Wide Web, where it has become accessible on the homepages of television channels or video-sharing websites like youtube.com. The television series $A$ Guerra. Colonial | Do Ultramar | De Libertação (Joaquim Furtado 2007-2010) is exemplary for this process, as it draws on archival material, has been edited on DVD and can be accessed via youtube.com or other portals. The series is also central to current discussions on the decolonization of Portuguese Africa regarding the use of testimony: different actors from all sides speak about their experiences in those wars, and the director Joaquim Furtado uses their accounts to construct a complex and often contradictory narrative about the end of Portuguese colonial rule in Africa.

The television series directed by Furtado is, however, only one important event in the filmic and televisual discussion of the colonial past. And in order to better understand the character of recent productions that often emphasize multiple perspectives and the relevance of individuals for the reconstruction of historical events, an examination of films that emerged in the 1990s turns out to be of crucial importance. In that decade, due to a variety of factors, including the end of the Cold War and the end of the civil war in Mozambique in 1992, a range of films were produced that address Mozambican-Portuguese history on a more biographical level. ${ }^{2}$ These films largely abandon the type of 
argument that prevailed in productions of the 1970s, whose anti-colonialist/ anti-imperialist meta-narratives were constructed through the use of voiceover narration superimposed on historical footage. ${ }^{3}$ Furthermore, the increasing importance of testimony in documentary films since the 1990 s also involves another dimension. Often, such accounts are used not to accuse colonial attitudes, but rather to explore how historical reality is perceived by people who experienced it. And in addition to filmic interventions that consider the colonial past critically, one also has to take into account views that highlight the impact of late colonialism in a more positive manner and that became more frequently articulated in the 1990s in Portugal (Chabal 1999: 70). One finds such a rather nostalgic perspective in Moçambique. No outro lado do tempo (Com Som, 1997).

Against this backdrop, it is hence evident that a filmic negotiation of the Portuguese colonial past gained a new dynamic in the 1990s. Such audiovisual productions constitute a heterogeneous field that provides an important opportunity to examine particular articulations regarding post-colonial and post-authoritarian understandings of the end of the Portuguese empire. In analysing some selected examples, I thus follow the incentive of Cláudia Castelo, who argues:

We want to reflect on colonial representations with regard to their persistence in the post-colonial present. We are less interested in the images of the colonial past and the remembrance of these images than in the modes and logics of reconfiguration of such images in the present as a function of considering actuality and concerns of particular social groups.

(Castelo 2005/2006: 11-12, my translation)

In order to do this, I will focus on two quite different perspectives on the Colonial War articulated by two Portuguese documentary films. These films crystallize important tendencies sketched out above and allow for describing Portuguese perspectives on the war in Mozambique in a differentiated manner. The first film is Guerra Colonial. Histórias de Campanha em Moçambique by Quirino Simões. It was produced in 1998 and distributed with the weekend issue of the daily newspaper Diário de Notícias in the form of a videotape. Although there were also films about the war in Angola and Guinea in that edition, I concentrate here on Mozambique because in the second half of the 1990s, film-makers paid considerable attention to this East African country. Among a wide range of material, I chose Natal 71 (1999) by Margarida Cardoso for the second case study presented in this article. This film is a well-known documentary about the Colonial War in contemporary Portugal. It has been frequently screened at film festivals and is available on DVD. While Guerra Colonial. Histórias de Campanha relies primarily on voiceover commentary and moving images from official archives, Natal 71 offers a different perspective on the war in Mozambique through the use of testimony and photographic images from private collections.

In order to analyse the creative strategies implemented by the film-makers, I will draw on an interdisciplinary research perspective. I will base my arguments theoretically on the notion of the archive, which I will bring up in the next paragraph. Regarding methodology, I draw on film analysis and, in particular, on works about documentary film that examine techniques like montage or slow motion and the relationship between voice, music, sound and visuals (Bruzzi 2000; Fischer 2004; Dancyger 2011). The two case studies constitute the main part of the article. Finally, I will present some concluding
2. La double vie de Dona Ermelinda (Aldo Lee, 1995); A procura de Xosé (Sara Miranda, 1999); Regresso a Nacala (Joana Pereira Leite, 2001).

3. Deus Pátria Autoridade (Rui Simøes, 1975); Estas são as armas (Murilo Salles, 1978). 
remarks and contextualize the selected examples by pointing out other audiovisual negotiations of the colonial past.

\section{SOME REMARKS ON THE CONCEPT OF THE ARCHIVE}

There is no political power without control of the archive, if not of memory.

(Derrida 1995: 11)

Derrida points out that 'nothing is less clear today than the word "archive" (1995: 57). It is mostly associated with certain places like state institutions, libraries, museums and so on, where documents of public interest are stored and preserved (Manoff 2004: 10). Contrary to this common idea, Foucault and other theorists have been interested in conceptualizing the archive as the 'law of what can be said' (Foucault 2010: 129). In this sense, the archive is not 'the library of all libraries', nor is it 'that which collects the dust of statements that have become inert once more, and which may make possible the miracle of their resurrection' (Foucault 2010: 129). It is rather 'the first law of what can be said, the system that governs the appearance of statements as unique events' (Foucault 2010: 129). This emphasis on the archive's discursive dimension is a necessary and instructive concept that alludes to a wider notion of archive, which is not restricted to a specific place but rather takes into account societal discourses of power, history, colonialism and anything else that is interlinked with it. A concept that tends to concentrate mainly on discursive formations like the one designed by Foucault does not, however, sufficiently consider the involved subjects that perform processes of recording, archiving and interpreting. In this respect, it seems productive to draw on Derrida's reflection about the archive as a site, where the archons 'are first of all the documents' guardians. They do not only ensure the physical security of what is deposited and of the substrate. They are also accorded the hermeneutic right and competence. They have the power to interpret the archives' (Derrida 1995: 10).

These authorities are not ahistorical, however, which means that the aforementioned configuration is historically specific and subject to alterations. This aspect often emerges in situations of political change, above all from authoritarian or dictatorial regimes to democratic forms of political rule. While the archives of the former are kept under strict control and offer access to only a limited number of persons loyal to the regime, democratization often facilitates 'the participation in and the access to the archive, its constitution, and its interpretation' (Derrida 1995: 11).

Given the engagement of a series of actors related to activities that shape the archive, it becomes necessary to reflect about the nature of its content, the 'documents'. It is important to be aware that the files that constitute the archive do not reflect historical reality in a literal sense, or springs of knowledge or truth. They rather imply questions of authorship and are related to production of authenticity and credibility in different types of (historiographical) discourses (Guha 1994: 51). Files, whether they are written documents, images or other material objects, are hence intertwined with 'power as well as hegemonic ways of interpretation, purposes and forces, that are interrelated with the collection, order and accessibility of formations of knowledge' (Büschel 2010: 76). Consequently, archival documents were and are produced due to certain social and political circumstances, and are hence connected to specific 'evidentiary paradigms' (Ginzburg 1989). Furthermore, the methods that enable their preservation and storage also result in a specific shaping 
of knowledge: '[t]he archivization produces as much as it records the event' (Derrida 1995: 16). 'Archives' are thus not merely places for storage, but rather places of knowledge production (Dirks 1993).

The discussion of 'colonial archives' (Stoler 2002) in documentary films through extraction and insertion into new contexts therefore points to the envisioning, questioning and renegotiation of the power-knowledge relations inscribed into the audiovisual documents. Within the framework of post-colonialism, images and meanings connected to them are thus recontextualized and reinterpreted through diverse strategies. Among them, we find the audiovisual testimonies of witnesses, perpetrators or victims (Sarkar and Walker 2010). Such accounts have a significant impact on the reinterpretation of footage and have the ability to create other versions and visions of the past. By and large, one can state that the negotiation of the colonial past in documentary practice through the discussion of '(post-)colonial archives' and the uses of testimonies can be conceived as a mode of politics of memory in a post-colonial field (Chakrabarty 2005; Schwelling 2010), to which different actors make their contributions and which is located in different time periods and socio-political contexts. The following case studies shed light on such processes by analysing the negotiation of the Portuguese colonial past articulated in documentary films.

\section{GUERRA COLONIAL. HISTÓRIAS DE CAMPANHA EM MOÇAMBIQUE (1998)}

\section{Mirroring historical reality}

The video Guerra Colonial aims to depict the Colonial War in Mozambique. It is divided into nine chapters that establish a chronological order and narrate the antecedents, the war in the Cabo Delgado and Niassa provinces, largescale military operations and so on. As the opening sequence of the film crystallizes the film's attitude towards the use of archival material, I will begin by examining its two parts: The first is composed of black-and-white footage, the second of an animation.

The initial scene is a montage of several shots: an aerial view of two flying helicopters, a medium shot of a helicopter pilot and two shots of a platoon of armed soldiers running through the bush from a high-angle perspective. The film then cuts to a close-up of a soldier using a communication device. ${ }^{4}$ The ultimate shot shows three wounded Africans receiving medical treatment. Using a particular selection of the audiovisual archive of the New State, the scene thus aims to reconstruct a typical counter-insurgency military operation that here serves to represent the wars of decolonization as a whole. By demonstrating the African subjects at the end, it also suggests that the operation was a success and that the adversaries were arrested, hence insisting that Portugal's military engagement in the colonies was legitimate and successful, a view that predominates in the film, as the following paragraphs will show. This visual narrative is bound together by the audio track: the continuous noise of a flying helicopter complements the visual and adds an intrinsically significant element to the filmic representations of war (Elsaesser and Hagener 2010: 141).

The second part of the opening scene is an animation. Here, the main objects are a book, a map and a globe. An open, weighty tome appears on the screen and is set on a map of Angola. On its turning pages, the moving images of the footage used in the introductory scene are inserted. Simultaneously, the animation creates a rotating globe that emerges from the book and is zoomed in on; it then focuses on Africa and the territory of Mozambique. It is a rather
4. Viewers may recognize Daniel Roxo in this shot, one of the important military elites of the war in Mozambique. Portuguese authorities saw him as a heroic figure, but he was also known for his ratherviolent methods (Magaia 2010: 170). 
simple animation, but it can be understood as a significant marker that hints at the way the film treats the used footage and the status that it ascribes to the archival images. Regarding the first point, one can argue that the black-andwhite images in this film try to constitute facts; they seem true and authentic. If one puts them together, one would be able to write 'history', here understood as a correct and true representation of past events - as if written history would mirror 'reality' (Rosenstone 2001: 51). What is implicit here, however, is a concept of the documentary film as a form of representation that provides direct access to historical reality and whose 'historical images, through their indexical relationship to actual people, landscapes and objects, can provide a virtually unmediated experience of the past' (Rosenstone 2006: 17). Images, it seems, 'are'; they were not produced. The complex circumstances of the production of these images are not discussed in the sequence whereby a simple relationship between reality and its possible translation to film is suggested. This claim for truthfulness and objectivity surfaces in the advertisement for this video collection as well: Nobody said "Lights, camera, action." But in truth, action is not missing in this video' (reproduced in Power 2001: 465). Here, the status of the utilized material in the film as a truthful and credible representation of what happened is asserted by stating that these images were neither staged nor created under the conditions of a planned enactment, which is common in film studios.

The outlined gesture of authenticity and truthfulness recurs to a powerful symbol of objectivity: a history book that seemingly tells how it really happened' (J.G. Droysen). Moreover, this type of book is written by historians whose work comprises carefully using documents found in the archives as elements of a certain narrative. But when thinking about the authorship of the film, its claim for a truth about the war in Mozambique turns out to be ambiguous. The director and scriptwriter of the film, Quirino Simões, born in 1931, was a member of the armed forces and became a film-maker in the 1960s. Working for the Service of Information of the Armed Forces and the National Ministry of Defence, he did a series of documentary films in and about the wars in Angola and Mozambique (Cruz 1981: 129; Monteiro 2008). Having the film-maker's background in mind, one inevitably has to question the approach considering the archival material in the analysed documentary. Obviously, Simões was more than familiar with the films he once directed and now uses as a tool for creating a history of the war in Mozambique. One could argue that the claims for truth in Guerra Colonial and its advertisement are only a commercial strategy. But, as public and academic discussion of such 'war films' in general and the 'Colonial War' in particular was only emerging at the time, one can also assume that the aim of such claims was to ascribe credibility and persuasiveness to the video, not as entertainment, but as a particular form of popular historiography (Eitzen 2005: 410).

\section{VOICE-OVER AND AUTHORITY}

A central strategy of Guerra Colonial is that it strongly relies on the explanations provided by the voice-over, used here as an 'explanatory and persuasive tool' (Bruzzi 2000: 56). This is a common feature of historical documentary films in which a narrator speaks 'while we see recent footage of historical sites intercut with older footage, often from newsreels, along with photos, artefacts, paintings, graphics, newspaper and magazine clippings' (Rosenstone 2001: 50). The images serve primarily, but not exclusively, as we will see 
below, as an illustration for the argument brought forward by the so-called 'voice of God', and they create evidence when used in a 'realist mode' (Arthur 1997: 4). By and large, the argument of these films is presented in an 'expository mode' in which the commentary is 'presumed to come from some place that remains unspecified but associated with objectivity or omniscience' (Nichols 2001: 168). That is, however, an aspect that one can question regarding Guerra Colonial. The reason for this is not only the background of the filmmaker, but also the commentary itself.

As it turns out, the narrative of the documentary Guerra Colonial appears to be connected to a perspective shaped by members of the 'Commando level'. This is particularly evident in the parts of the film dedicated to the 'near [...] annihilation of the guerrilla' and the large-scale military operations like Nó Górdio and Operação Fronteira. In these sequences, the voice-over addresses the new strategies (demining of itineraries, having the air force supply isolated bases) introduced by General Kaúlza de Arriaga, who became the commander in chief of Mozambique in 1970, and the 'success' of large-scale operations under his command (Newitt 1995: 531). Although there are no direct quotations, a number of explanations refer to Arriaga:

Following the opinion of General Kaúlza de Arriaga, given the systematic exploration of the success, the total victory of the Portuguese troops in Cabo Delgado would have been foreseeable had the front in Tete not been opened [by Frelimo], a fact that originated above all in the protection of the construction of the Cahora Bassa Dam.

(Guerra Colonial, 00:20:05-00:20:26, my translation)

The emphasis here is clearly on a military and strategic point of view that has a very narrow focus, which in turn supports the idea of Portuguese victory that prevented Frelimo from installing a liberated zone in the northern provinces of Niassa and Cabo Delgado. Although the commentary also affirms that the Portuguese armed forces eventually did not succeed, it explains that this happened not due to their efforts or military strategy, but was rather an effect of the construction of the Cahora Bassa Dam. Consequently, the film reproduces a view found in publications by Arriaga, who always affirmed the claims of victory in Mozambique (Arriaga 1977: 65-70). A number of scholars, however, do not confirm this point of view. Chabal affirms:

In Mozambique, [...] the Portuguese did manage to seduce some FRELIMO dissidents, but their much-trumped Gordian-knot counterinsurgency drive had only transient effect. FRELIMO soon counter-acted the Portuguese military gains and opened new fronts in the centre of the country. Despite the claims of the Portuguese military commander, General Kaúlza de Arriaga, the colony of Mozambique could not be considered secured either politically or militarily.

(Chabal 2002: 16)

Arriaga's way of seeing the war in Mozambique continues to emphasize a victorious interpretation, even decades later. Medeiros criticizes such an attitude:

[I]n 1993 it is still possible for one of the principal men implicated in the Colonial Wars, General Kaúlza de Arriaga, military commander in Mozambique from 1969 to 1973 , to deny the reality of much of the trag- 
5. Scholars investigating historical films often accuse them of distorting history (Fendler and Wehrheim 2007: VIII, XIII; Guynn 2006). edy of the war. Not only does he deny the significance of the massacres of civilians by the troops under his command, he also denies the disastrous conditions of the war, preferring to see the events of 1974 and the subsequent independence of the colonies as acts of political treason.

(Medeiros 2000: 209-10)

By pointing out the evaluations of these scholars, one perceives that Guerra Colonial does not allow critical comments regarding the efforts of General Arriaga. One could thus argue that this documentary not only constructs a specific narrative about the war in Mozambique, but even tends to distort the history of its decolonization. ${ }^{5}$ Although such an interpretation seems legitimate, it is also instructive to analyse such an audiovisual articulation 'as part of a separate realm of representation and discourse, one not meant to provide literal truths about the past [...] but metaphoric truths which work, to a large degree, as a kind of commentary on, and challenge to, $[\ldots]$ historical discourse' (Rosenstone 2006: 8-9). Guerra Colonial confirms and hence (re)produces a certain discourse of military history, which emerges in the numerous remarks on information that have a rather statistical character. In this respect, one can refer to a number of volumes on the development of the wars in Angola, Guinea and Mozambique. These volumes are mainly based on data and historical maps published by the chief of staff (that is, Comissão para o Estudo das Campanhas de África 1989) or Guerra Colonial (Afonso and Gomes 2000), a rather descriptive account of the events with a focus on military strategies, operations and used weapons. But these rather neutral-appearing numbers are mentioned together with references to Arriaga, which contribute to downplaying and neglecting problematic aspects of the war. Therefore, the film can also be perceived as a comment on more critical accounts that condemn the 'wars overseas', a process that happened above all in the post-revolutionary period after the coup d'état on 25 April 1974. One could think, for instance, of a controversial literary work like Os cus de Judas (The South of Nowhere 1979) by António Lobo Antunes, in which the protagonist of the novel radically denounces the Salazar regime and the war after returning from his military service in Angola. Against this backdrop, one can argue that Guerra Colonial and its archival politics tries to stimulate a revision of this condemnation and advocates the recovery of an attitude among veterans and others, which would be not so much shaped by 'shame' (Campos 2008: 107), but rather by honour and pride.

\section{COMMANDOS ATTACKING}

Characteristics like honour and pride also seem to be significant when considering the image of the Commandos, Special Forces of the Portuguese Armed Forces. The film constructs the Commandos by drawing on particular cinematographic strategies. It mainly employs material that gives visibility to the following topics: armed soldiers that move through grasslands and forests, attacks on (already abandoned) Frelimo base camps, captured weapons and the apprehension of guerrilla fighters. Such material has to be regarded with scepticism, as it ignores the frequent and violent attacks meant to 'clean' of a particular zone (West 2005: 147). However, scenes with such motives appear frequently; it seems that they are used in order to further support the idea (expressed by the voice-over) of a war that was nearly won. Consider the films quoted in Guerra Colonial like Moçambique. Missão de Combate (Quirino Simões, 
1968) and Operação Nó Górdio (Serviço Cartográfico do Exército, 1970). In such films, a rather simple and linear narrative predominates, demonstrating one operation, one attack and then the captured weapons as trophies. Like many other film productions of the New State (Grilo 2006: 81-87; Paulo 2011), such films were intended to legitimate the military engagement in Africa and therefore neglected the negative effects that affected all people involved in the conflict. In the video Guerra Colonial, however, one is confronted with various attacks, various occupations of Frelimo bases and the detention of suspects. Although this structure could be seen as corresponding to a chronological order of the war that indicates a number of incidents that happened, it does not equally enumerate the attacks by the Frelimo, whose members are only shown in very few scenes. ${ }^{6}$ As a result, the film presents the Portuguese Special Forces as the dominating actor in the territory.

The process that leads to the heroization of the Commando units is achieved through different techniques, starting with the idea that the used footage actually shows combat action. It suggests that these archival images are not staged shots captured by a handheld camera. Such blurred shots are frequently used to show what preceded attacks on guerrilla bases. It is an aesthetic strategy that emphasizes the unmediated character of the footage. By relying on 'T'effet du réel' (Barthes 1989), the used footage makes one forget that people stand behind the images that make up a historical documentary (Toplin 1998: 1217).

Another technique used in the scenes about military operations concerns the soundtrack: while the voice-over guides the understanding of the images in most parts of the film, there are some sequences in which they are framed by extra-diegetic music. In these, the film-maker seems to play with the staged images of war in a creative manner; the footage showing attacks on Frelimo bases is juxtaposed with synthesizer melodies and dubbed war sounds. The music aims to create suspense, and its use in this context somehow fictionalizes the (staged) documentary images (Comer 2002: 358), ascribing to them an aesthetic reminiscent of war films (Chapman 2008).

Besides combat action, the characterization of the Portuguese army also results from showing other activities. As the film argues, the special forces were, together with engineering units, engaged in vaccination campaigns, in educational programmes and in building aldeamentos, protected villages that supposedly 'improved' the living conditions of the local populations (Pinto 2001: 53). This verbally and visually conveyed characterization strongly refers to values propagated by the authoritarian regime, reiterates the usual items of its propaganda (Grilo 2006: 85) and thus tends to reproduce its arguments. This kind of colonial paternalism is crystallized in a statue that can still be found in Coimbra: a monument of a Portuguese soldier carrying an African baby on its shoulders. This statue was erected before 1974, removed after the end of the regime and put up again at the Praça dos Heróis do Ultramar some years ago, a vital signal for the 're-legitimization of colonialism and war' (Rosas 2005).

Regarding the other parts of the video, the profile of the Commandos and militias also gains credibility by a selective view of the Frelimo soldiers. Shots that show the guerrillas only present them as a military adversary, participating in parades or ambushing Portuguese bases, therefore neglecting that Frelimo was engaged in medical and educational campaigns, and in interaction with local communities as well (Henriksen 1983: 145-50). None of these elements is used in Guerra Colonial because this would have had the effect of
6. These shots were mostly taken from the film Behind the Lines (Margaret Dickinson, 1971). 
recognizing that both sides were interested in 'winning the hearts' of the rural populations.

A final aspect that contributes to the image of the Portuguese armed forces as a strong and above all white force in the territory is the references to the participation of African recruits, designated voluntários. This notion comes from the propaganda of the New State, which claimed that these volunteers were defending Portugal against guerilla attacks. Notice that the reasons for Portugal's Africanization policy were largely pragmatic and practical and they suited Portugal's general policy of making the colonies pay their own way and subsidize themselves, wherever and whenever possible' (Wheeler 1976: 239; see also Coelho 2002: 137). Regarding the archival images used in the film, one gets the impression that the attacks on guerrilla bases and the detention of guerrilla fighters were mostly performed by white Portuguese soldiers. So there is not only a kind of heroization of the Portuguese Commando units - an image already created by the New State propaganda (Afonso and Gomes 2000: 198-207) - but also a simultaneous marginalization of African conscripts, who had been a constitutive element of the Portuguese armed forces since the second half of the 1960s (Power 2001: 485, 487; Coelho 2002: 145). Consequently, the use of these particular war films in Guerra Colonial perpetuates a filmic space shaped by colonial discourses in which imagined white 'majorities' conquer, pacify and finally inhabit the African territories, while elements of the local populations merely figure in secondary roles (Ukadike 1994: 22-48).

\section{NATAL 71 (1999)}

More recently, filmmakers speak in their own voices on the sound track. This change stresses the personal perspective of the maker and foregoes the claim to ultimate wisdom or impartial truth that is common to voice-of-God commentary.

(Nichols 2001: 169)

\section{THE FILM-MAKER IN THE ARCHIVE}

While Histórias de Campanha em Moçambique uses a rather conventional structure that tends to make the author and place of production disappear, Natal 71/Christmas 71 (Margarida Cardoso, 1999) deals differently with such issues. In her documentary, Margarida Cardoso appears frequently in front of the camera. This technique of reflexivity is applied in order to acknowledge the personal dimension of the film, its subject and its focus on the experiences of her father's military service in Mozambique. At the beginning of the film, a female voice-over explains the film-maker's motivation:

On Christmas '71, I was in Mozambique. My family accompanied my father, a career soldier, who took part for 13 years in an absurd war defending the Portuguese colonies. From that era of fascism, repression and war, I retain childish but very present memories. Although these events greatly influence our behaviour today, my father and I rarely talk about them. Why? Today, I look back and try to understand.

(Natal 71, 00:02:16-00:02:51)

Cardoso's biography is thus connected to Mozambique in a particular way and serves here as the determining trigger for the film, which initiates a 
dialogue between the ones who participated in the war and 'a child of the war' (Martins 2012). ${ }^{7}$ The documentary film in this case becomes a site for the 'transgenerational transmission of memory' (Marques and Paez 1997) and allows for the negotiation of the colonial and authoritarian past. It goes beyond the assumption that 'all the facts are knowable and their meanings understandable' (Toplin 1998: 1216) and questions perspectives that are taken for granted, like those presented in Guerra Colonial.

The critical attitude about the Estado Novo that Cardoso expresses in the statement mentioned above also surfaces in the treatment of the footage taken from official archives and is evident from the very beginning of the film. Here, one is confronted with a juxtaposition of black-and-white footage showing the marching youth of Mocidade Portuguesa in Estádio Nacional and a long quote from Os cus de Judas (1979) by António Lobo Antunes. The cited passage describes the fate of a whole generation of men who grew up under the regime of Salazar, became members of patriotic mass organizations and were sent to Africa, where they finally died. The nature of the moving images is questioned by the monologue of an anonymous protagonist, who reflects about his experience in the war in Angola after having returned home to Lisbon. Consequently, the montage of footage produced by the New State with excerpts from Antunes's novel problematizes the images and suggests that they are deeply intertwined with the official discourse of the regime (Azevedo and Saramago 1999; Cádima 1996).

The film-maker's critical attitude towards the official visual archive of the Estado Novo is articulated in a series of further scenes, whereby the use of certain filmic techniques de-naturalizes the reality effect associated with moving images. The first strategy consists of a reflection on the research undertaken by Cardoso in filmic archives. There are shots that show how the reel is put on the editing table. Another shot captures the moving reel in such a way that one can nearly distinguish the single frames. And yet others demonstrate how Cardoso operates the editing table. It is important to note that all these shots are close-ups that create a sense of proximity to the film-maker and her project of questioning the appearances on the screen. This creation of a filmic space that focuses on the interaction between subject and technical equipment also highlights the material dimension of the film medium. As a result, the film-maker is established as a figure who gained access to the archives (which before 1974 were normally limited to a certain group of persons loyal to military and political doctrine) and is now about to challenge the rules of their interpretation.

Hence, besides the reflection of her role in the production of the film, Cardoso uses different cinematic strategies connected with various functions in order to invest the footage with new meaning. The first of them is slow motion. A striking example for its application is a shot in which the camera follows soldiers searching for anti-tank mines on a path. Cardoso lets the footage pass slowly, focusing on the stick with which the ground is prodded in order to identify explosive materials. There is no horizon in these shots, only the boots moving forward, step by step, following the stick that seems to provide a sense of security. As Walter Benjamin notes: "slow motion not only reveals familiar aspects of movements, but discloses quite unknown aspects within them" (Benjamin 2008: 37). The scene shows the difficult, dangerous process of demining and could also be understood as a way of counteracting the claims for victory in Mozambique articulated by the former military elites mentioned above.
7. Cardoso's feature film, A costa dos murmúrios (2004), an adaption of the novel of the same name by Lidia Jorge (1988), also addresses the war in Mozambique and depicts it from a feminine point of view. 
A further technique that creates a distance from the utilized archival images is the capture of projected film and video on television. In this case, certain camera angles, and sometimes the creation of a filmic space in which individuals interviewed by Cardoso are shown watching black-and-white images on the screen, contribute to a modification of the projected images. This in turn allows the film to produce distance from and scepticism about the images that are shaped by the politics of the authoritarian regime and a specific evidentiary paradigm.

\section{LEAVING THE OFFICIAL ARCHIVE}

The film is not, however, limited to reflections on the role of the film-maker and the process of investigating the filmic archives of the New State. It rather convincingly shows that other locations - outside the institutionalized places - and their exploration provide opportunities to negotiate memories, thus enabling the creation of different insights into a historical period. The most crucial site to which the film takes its viewers in this respect is the house of the film-maker's parents. Here, Cardoso encounters the vinyl entitled Natal 71 (Christmas 71), a propaganda product of the Salazar regime made by the Movimento Nacional Feminino (MNF) (Ribeiro 2007; Santo 2003). The vinyl is one of the important objects that guide the film's discussion of how the cultural production of the New State functioned. But there are also other items, such as an audio cassette that contains a recording of the Cancioneiro do Niassa, a number of protest songs that circulated clandestinely in Mozambique and the colonies in the 1970s (Basto 2006: 105-06; Guerra 1994: 259), as well as a photo album of her father containing numerous snapshots of the time he and the family spent in Mozambique. All of these objects are captured in a few shots, while also showing her father, Adelino Cardoso, listening to the record by the MNF and looking at a photograph of himself from the time of his service in Mozambique.

Thus, the place differs from the audiovisual archives of the Portuguese armed forces and Radio Televisão Portuguesa (RTP). This also has consequences for the way in which the past conflict is perceived and how the items related to it are interpreted. In other words, the rules of interpretation (Derrida 1995: 10) of the objects preserved in this particular collection are not valid, for example, in the domain of (military) historiography. One of the many comments in which Adelino Cardoso expresses his view on the war in Mozambique is instructive for grasping this aspect:

People have their own theories about [the wars in Africa]. Fine. They know what they're saying, I'm sure. But what they all lack, or what most of them lack, is the actual experience of having been through it. Theorising about something as complex as everyday life at war is difficult.

(Natal 71, 00:45:57-00:46:22)

The former pilot's comment alludes to an archive constituted by articulations, opinions and written accounts on the war of decolonization that aim to appropriate and interpret the complex historical experience without recognizing a subjective viewpoint, which is also true for Guerra Colonial. Contrary to this, Natal 71 engages the individuals that participated in the historical events and the making of the propaganda record. It takes a look behind the scenes by offering testimonies of the involved artists and technicians, as well as the musicians and 
former soldiers. Here, the discussion of the archival images is intertwined with extracts from video interviews. This documentary does not focus on the history of certain battles, but rather on a subjective perspective in which the biographical narration of the interviewees emerges and is of crucial importance.

\section{TESTIMONY, PHOTOGRAPHY AND EVIDENCE}

Through the use of testimonial accounts given by artists and former soldiers, Cardoso convincingly questions the authority of the visual material that belongs to the official archive. The film thus discusses the symbolic and cultural legacy of the New State and argues for a reflection on the war of decolonization that contrasts with the one articulated in Guerra Colonial. Historias de Campanha em Moçambique. A striking example of this proceeding is an account given by João Maria Pinto on the character of the war in the province of Niassa. Pinto, a musician and songwriter who was involved in the writing of the protest songs of the Cancioneiro do Niassa and who is one of the protagonists of the film, is interviewed in a dimmed room in this scene. Illuminated indirectly by the slide projector, he is framed by a medium close-up. While smoking, Pinto speaks about his experience as a soldier in Mozambique and how he went to Lake Niassa for the first time. Confronted with the overwhelming landscape of the huge lake, he remembers how he began to reflect about the reasons for his presence in that scenario:

On my first mission in the bush, we headed for Lake Niassa. We reached a viewpoint where we had to stop. We saw the lake down below, on a lovely clear day. And it was a huge lake. The first thing I thought was, 'How many miles am I away from home?' Away from my parents, my village, my own people, the people I identify with? What have I come here to defend? I can sense, on the horizon, the bush that belongs to no one. This is Africa. It belongs to a tribe, a people, I don't know who, but it doesn't belong to us. We shared only one thing: a piece of ground without mines, our own bit of territory.

(Natal 71, 00:42:50-00:43:44)

The audiovisual testimony of Pinto is intercut with (coloured) photographs, a common practice in historical documentaries. These images serve not only as an illustration but also as an evidence-producing element. They are connected to Pinto's explanations through filmic montage, and one therefore assumes that the interviewee was the one who took them. It is a process that hence conveys the idea that Pinto was there in Mozambique, and it asserts his passage over muddy tracks that cut across wide landscapes and seemingly impenetrable forest. Towards the end of the testimony, the view of the lake mentioned by Pinto is presented. However, the exotic beauty of that moment had an inverse effect and resulted in a dissociation regarding the officially propagated national unity à la 'Do Minho a Timor'. Pinto neither identifies this territory as a part of his country nor refers to any kind of military success that characterized the war in Mozambique. Rather, he describes the military situation in Mozambique at the beginning of the 1970 s by pointing out that the whole region was mined and that they could only be sure of the little piece of land actually beneath their feet. Consequently, by stressing the finiteness of colonial space, Pinto's account destabilizes the idea that 'Portugal is not a small country' (Sanches 2006: 7). 
8. The concept of 'ways of seeing' was introduced by John Berger (1977).
In Natal 71, testimony and photographs from private collections are used to create a specific vision of the Colonial War 'from below'. The images, which were preserved in private spaces, appear on the screen and stimulate memory. While seeing or remembering them, the protagonists reflect on their biographies and experiences in the war. When photographs come out of storage, it is as if energy is released' (Hartmann, Silvester and Hayes 2001: 2). Here, this energy can be understood as a form of counterbalance that may unsettle and challenge representations that mainly rely on images from the official archives of the New State and often tend to reproduce its discourses.

\section{CONCLUSION}

Since the middle of the 1990s, there has been a growing interest in the visual dimension of colonial and African history. Various scholars engaged in research on photography in colonial Namibia and the British Empire criticized the illustrative use of this material in history books and affirmed that 'visuality is subordinated to textuality which itself is grounded and empirically validated by reference to documents and sources from the privileged site of the archive' (Hartmann, Silvester and Hayes 2001: 2). But when acknowledging the complexity of images, one can analyse them as 'expressions of the knowledge and power that shaped the reality of Empire' (Ryan 1997: 19-20). Many researchers have followed this approach since then and have explored the use and function of visual artefacts from the colonial period in post-colonial contexts as well (Medeiros 2002; Thackway 2007: 93-118; Hoesen 2010; Seabra 2011). These studies point to the cultural dimension of decolonization - a process that goes beyond the transfer of power - and recognize the importance of the visual in contemporary societies (Mirzoeff 2002; Arenas 2011).

The case studies examined above are exemplary for this and indicate - as other films also do - a similar relevance of audiovisual representations regarding the diverse readings of the colonial past in the context of the Portuguesespeaking countries. By investigating the different 'ways of seeing's the war of decolonization articulated in documentary films, one can grasp moments and processes that re-shape the perception of the end of Portuguese colonial rule in Africa. In this respect, the two selected examples presented in this chapter offer different approaches to negotiate the double legacy of colonialism and the authoritarian regime.

The argument of Guerra Colonial. Histórias de Campanha em Moçambique is mainly informed by interpretations of the war given by former leading militaries. It foregrounds a victorious perspective by emphasizing military action that took place in the northern provinces of Niassa and Cabo Delgado while downplaying the situations in Manica, Sofala and Tete. It is a discourse of popular military history that largely ignores the negative effects of the wars that are still noticeable in Portugal (Santos Lourenço and Keese 2011: 240). The film also constructs a heroic image of the Commandos, mainly through the use of music. Though using a rather conventional style that suggests objectivity, it is evident that the film's narration works with omissions and selections, thereby marginalizing the experiences of both African and Portuguese soldiers. This production is one of those documentaries that 'rarely give audiences a sense of the challenges in historical interpretation. They address subjects authoritatively, suggesting that the investigator works with an orderly universe of evidence' (Toplin 1998: 1216). 
In contrast, Natal 71 problematizes the nature of archival images and aims to establish a practice of testimony in order to consider a more subjective perspective on the war. It does so by relying on accounts that mostly argue for the emergence of a political consciousness regarding the war and the regime before 1974. In this sense, Cardoso's film creates a story of decentralized resistance and protest on the basis of different biographical experiences beyond the horizon of political parties, while also dissenting a view that insists on a Portuguese victory in the war in Mozambique. Its focus on micro histories, however, results in the construction of a perspective that only slightly relates to a larger historical context.

As indicated at the beginning of this article, both films have a specific place in a field in which the end of the Portuguese empire has been addressed by a great variety of documentary and feature films since 1974. It is a theme that was and is debated by film-makers and other people who come from African and European countries. Regarding the latter, this article demonstrates that a variety of perspectives on the violent process of decolonization exist. One therefore has to be cautious when speaking of a homogeneous Portuguese memory of the war in Mozambique, as the different generations and the veterans themselves differ considerably in their viewpoints and recollections. With this in mind, one has to acknowledge that the documentaries examined above - and many other films as well - enable the negotiation of the memory of decolonization; that is, they recycle and perpetuate discourses shaped by the New State or produce partial truths (Rabinowitz 1993: 128) about this chapter of history. The films proceed in specific ways and invent their own evidentiary paradigms. As part of global media flows, such films inform contemporary understandings of the colonial past and therefore require further scholarly attention.

\section{REFERENCES}

Afonso, A. and Gomes, C. M. (2000), Guerra Colonial, Lisbon: Notícias.

Antunes, A. L. (1979), Os cus de Judas, Lisbon: Vega.

Arenas, F. (2011), Lusophone Africa: Beyond Independence, Minneapolis: University of Minnesota Press.

Arriaga, K. (1977), A luta em Moçambique, 1970/1973, Braga: Intervenção.

Arthur, P. (1997), 'On the virtues and limitations of collage', Documentary Box, 11: 3, pp. 1-7.

Azevedo, C. and Saramago, J. (1999), A censura de Salazar e Marcelo Caetano: Imprensa, teatro, cinema, televisão, radiodifusão, livro, Lisbon: Caminho.

Barthes, R. (ed.) (1989), 'The reality effect', in The Rustle of Language, Berkeley: University of California Press, pp. 141-48.

Basto, M.-B. (2006), Who is written? The representation of the other in rewriting experiments during the Portuguese colonial war and the Mozambican liberation struggle', in University of Utrecht (ed.), The Value of Literature in and after the Seventies: The Case of Italy and Portugal, pp. 94-112, unpublished conference paper.

Benjamin, W. (ed.) (2008), 'The work of art in the age of its technological reproducibility. Second version', in IBID. and Jennings, Michael W. (ed.), The Work of Art in the Age of Its Technological Reproducibility, and Other Writings on Media, Cambridge, MA: Belknap Press of Harvard University Press, pp. 19-55.

Berger, J. (1977), Ways of Seeing. Based on the BBC Television Series with John Berger, London: British Broadcasting Corporation and Penguin Books. 
Büschel, H. (2010), 'Das Schweigen der Subalternen: Die Entstehung der Archivkritik im Postkolonialismus', in A. Horstmann and V. Kopp (eds), Archiv-Macht-Wissen, Frankfurt a. M.: Campus, pp. 73-88.

Bruzzi, S. (2000), New Documentary: A Critical Introduction, London and New York: Routledge.

Cádima, F. R. (1996), Salazar, Caetano e a televisão portuguesa, Lisbon: Presença.

Campos, Â. (2008), "We are still ashamed of our own history': Interviewing ex-combatants of the Portuguese colonial war (1961-1974)', Lusotopie, 15: 2, pp. 107-26.

Cardoso, M. (1999), Natal 71, Lisbon: Filmes do Tejo (DVD).

Castelo, C. (2005/2006), 'Memórias coloniais: Práticas políticas e culturais entre a Europa e África', Cadernos de Estudos Africanos, 9: 10, pp. 9-22.

Chabal, P. (1999), 'Nós e a África: A questão do olhar', Africana Studia, 1: 1, pp. 67-84.

(2002), A History of Postcolonial Lusophone Africa, London: C. Hurst.

Chakrabarty, D. (2005), 'After history: Vergangenheit archivieren, erfahren und zerstören', Historische Anthropologie, 13: 1, pp. 121-35.

Chanan, M. (1985), The Cuban Image: Cinema and Cultural Politics in Cuba, London: British Film Institute.

Chapman, J. (2008), War and Film, London: Reaktion Books.

Coelho, J. P. B. (2002), 'African troops in the Portuguese colonial army, 1961-1974: Angola, Guinea-Bissau and Mozambique', Portuguese Studies Review, 10: 1, pp. 129-50.

Comissão para o Estudo das Campanhas de África (ed.) (1989), Resenha histórico-militar das campanhas de África: Dispositivo das nossas forças: Moçambique, Lisbon: Estado-Maior do Exército.

Convents, G. (2011), Os moçambicanos perante o cinema e o audiovisual: Uma história política-cultural do Moçambique colonial até à República de Moçambique (1896-2010), Maputo: CP - Conteúdos e Publicações.

Corner, J. (2002), 'Sounds real: Music and documentary', Popular Music, 21: 3, pp. $357-66$.

Cruz, J. de M. (1981), O cais do olhar: Fonocinema português, Lisbon: Instituto Português de Cinema.

Dancyger, K. (2011), The Technique of Film and Video Editing: History, Theory, and Practice, Amsterdam and Heidelberg: Focal Press.

Derrida, J. (1995), 'Archive fever: A Freudian impression', Diacritics, 25: 2, pp. 9-63.

Dickinson, M. (2011), 'Flashbacks from a continuing struggle', Third Text, 25: 1, pp. 129-34.

Dirks, N. (1993), 'Colonial histories and native informants: Biography of an archive', in C. A. Breckenridge (ed.), Orientalism and the Postcolonial Predicament: Perspectives on South Asia, Philadelphia: University of Pennsylvania Press, pp. 279-313.

Eitzen, D. (2005), 'Against the ivory tower. An apologia for "popular" historical documentaries', in A. Rosenthal and J. Corner (eds), New Challenges for Documentary, Manchester: Manchester University Press, pp. 409-18.

Elsaesser, T. and Hagener, M. (2010), Film Theory: An Introduction Through the Senses, New York: Routledge.

Fendler, U. and Wehrheim, M. (eds) (2007), 'Film und inszenierte Kolonialgeschichte', in Entdeckung, Eroberung, Inszenierung: Filmische Versionen der Kolonialgeschichte Lateinamerikas und Afrikas, Munich: Meidenbauer, pp. VII-XVIII. 
Fischer, L. (2004), 'Film editing', in R. Stam and T. Miller (eds), A Companion to Film Theory, Malden: Blackwell, pp. 64-83.

Foucault, M. (2010), Archaeology of Knowledge, London: Routledge.

Ginzburg, C. (1989), Clues, Myths, and the Historical Method, Baltimore: Hopkins University Press.

Grilo, J. M. (ed.) (2006), 'Gestos \& fragmentos. Cronologia crítica do "cinema de guerra" português', in O Cinema da Não-Ilusão. Histórias para o cinema português, Lisbon: Livros Horizonte, pp. 55-106.

Guerra, J. P. (1994), Memória das guerras coloniais, Oporto: Afrontamento.

Guha, R. (1994), 'The proses of counter-insurgency', in N. B. Dirks (ed.), Culture, Power, History: A Reader in Contemporary Social Theory, Princeton: Princeton University Press, pp. 336-71.

Guynn, W. (ed.) (2006), 'Introduction: Facing the skepticism of historians', in Writing History in Film, New York: Routledge, pp. 1-22.

Hartmann, W., Silvester, J. and Hayes, P. (2001), The Colonising Camera: Photographs in the Making of Namibian History, Athens: Ohio University Press.

Henriksen, T. H. (1983), Revolution and Counterrevolution: Mozambique's War of Independence; 1964-1974, Westport: Greenwood Press.

Hoesen, B. (2010), 'Weimar revisions of Germany's colonial past: The photomontages of Hannah Höch and Lászlo Moholy-Nagy', in V. M. Langbehn (ed.), German Colonialism, Visual Culture, and Modern Memory, New York: Routledge, pp. 197-219.

Magaia, A. (2010), Moçambique: Raízes, identidade unidade nacional, Maputo: Ndjira.

Manoff, M. (2004), Theories of the archive from across the disciplines', Libraries and the Academy, 4: 1, pp. 9-25.

Marques, J. and Paez, D. (1997), 'Social sharing, emotional climate, and the transgenerational transmission of memories: The Portuguese colonial war', in J. W. Pennebaker (ed.), Collective Memory of Political Events: Social Psychological Perspectives, Mahwah: Lawrence Erlbaum Associates, pp. 253-76.

Monteiro, P. F. (2008), 'Whispers, bullets and absent presences: Africa in Portuguese cinema', in University of Notre Dame (ed.), Africa in Portuguese, the Portuguese in Africa, unpublished conference paper.

Martins, A. (2012), 'Writing the nation beyond resistance: Portuguese film and the colonial war', Reoue LISA, 10: 1, pp. 271-79.

Medeiros, P. (2000), 'Hauntings: Memory, fiction and the Portuguese colonial wars', in T. G. Ashplant (ed.), The Politics of War Memory and Commemoration, London: Routledge, pp. 201-21.

(2002), 'War pics: Photographic representations of the colonial war', Luso-Brazilian Review, 39: 2, pp. 91-106.

Mendonça, E. (1993), O cinema produzido pelo serviço cartográfico do exército nas campanhas de Africa, 1961-1974, Lisbon: Faculdade de Ciências Humanas, Universidade Católica Portuguesa.

Minter, W. (2008), 'Interview with Robert van Lierop', in W. Minter, G. Hovey and C. E. Cobb (eds), No Easy Victories: African Liberation and American Activists Over a Half Century, 1950-2000, Trenton: Africa World Press, pp. $142-44$.

Mirzoeff, N. (2002), The Visual Culture Reader, London: Routledge.

Müller, J. (2011), Große Bilder mit kleinen Kameras: DV-Camcorder im Dokumentarfilm, Konstanz: UVK. 
Newitt, M. (1995), History of Mozambique, Bloomington: Indiana University Press.

Nichols, B. (2001), Introduction to Documentary, Bloomington: Indiana University Press.

Paulo, H. (2011), 'Documentarismo e propaganda. As imagens e os sons do regime', in L. R. Torgal (ed.), O cinema sob o olhar de Salazar, Lisbon: Temas e Debates; Círculo de Leitores, pp. 92-116.

Pinto, A. C. (2001), O fim do império portugués: A cena internacional, a guerra colonial, e a descolonização 1961-1975, Lisbon: Livros Horizonte.

Power, M. (2001), 'Geo-politics and the representation of Portugal's African colonial wars: Examining the limits of "Vietnam syndrome", Political Geography, 20: 4, pp. 461-91.

Rabinowitz, P. (1993), 'Wreckage upon wreckage. History, documentary and the ruins of memory', History and Theory, 32: 2, pp. 119-37.

Ribeiro, M. C. (2007), Africa no feminino: As mulheres portuguesas e a guerra colonial, Oporto: Afrontamento.

Rosas, F. (2005), 'Revivalismo colonialista', Publico, 27 April, http://www. publico.pt/espaco-publico/jornal/revivalismo-colonialista-17940. Accessed 20 September 2013.

Rosenstone, R. (2001), 'The historical film: Looking at the past in a postliterate age', in M. Landy (ed.), The Historical Film: History and Memory in Media, New Brunswick: Rutgers University Press, pp. 50-66.

- (2006), History on Film, Film on History, Harlow: Longman/Pearson.

Ryan, J. R. (1997), Picturing Empire: Photography and the Visualization of the British Empire, London: Reaktion Books.

Sanches, M. R. (2006), Portugal não é um país pequeno. Contar o 'império' na póscolonialidade, Lisbon: Livros Cotovia.

Santo, S. E. (2003), Adeus, até ao teu regresso: Movimento Nacional Feminino na guerra colonial (1961-1974), Lisbon: Livros Horizonte.

Santos Lourenço, I. and Keese, A. (2011), 'Die blockierte Erinnerung. Portugals koloniales Gedächtnis und das Ausbleiben kritischer Diskurse 1974-2010', Geschichte und Gesellschaft, 37: 2, pp. 220-43.

Sarkar, B. and Walker, J. (2010), Documentary Testimonies: Global Archives of Suffering, New York: Routledge.

Schwelling, B. (2010), Heimkehr - Erinnerung - Integration: Der Verband der Heimkehrer, die ehemaligen Kriegsgefangenen und die westdeutsche Nachkriegsgesellschaft, Paderborn: Schöningh.

Seabra, J. (2011), África nossa: O império colonial na ficção cinematográfica portuguesa 1945-1974, Coimbra: Universidade de Coimbra.

Simões, Q. (1998), Guerra Colonial. Histórias de Campanha em Moçambique, Lisbon: Diário de Notícias (VHS).

Stoler, A. (2002), 'Colonial archives and the art of governance', Archival Science, 2: 1-2, pp. 87-109.

Thackway, M. (2007), Africa Shoots Back: Alternative Perspectives in Sub-Saharan Francophone African Film, Bloomington: Indiana University Press.

Toplin, R. B. (1998), 'The filmmaker as historian', The American Historical Review, 93: 5, pp. 1210-27.

Ukadike, N. F. (1994), Black African Cinema, Berkeley: University of California Press.

West, H. G. (2005), Kupilikula: Governance and the Invisible Realm in Mozambique, Chicago: University of Chicago Press.

Wheeler, D. L. (1976), 'African elements in Portugal's armies in Africa (1961-1974)', Armed Forces \& Society, 2: 2, pp. 233-50. 
Willemen, P. (1991), 'The third cinema question: Notes and reflections', in J. Pines (ed.), Questions of Third Cinema, London: British Film Institute, pp. 1-29.

\section{SUGGESTED CITATION}

Stock, R. (2014), 'Archival images and audiovisual testimony - Negotiating the end of empire in the documentary films Guerra Colonial. Historias de Campanha em Moçambique (1998) and Natal 71 (1999)', International Journal of Iberian Studies, 27: 2+3, pp. 183-201, doi: 10.1386/ijis.27.2-3.183_1

\section{CONTRIBUTOR DETAILS}

Robert Stock holds a Master of Arts in European Ethnology. He also studied East European Studies and Portuguese Literature and Language in Berlin and Lisbon. He finished his studies with a thesis on museum representations of the Portuguese Colonial War in contemporary Portugal. His research interests are visual culture, post-colonial memory politics, museum studies and disability studies. Currently, he is working on a Ph.D. project about documentary films in which he examines the various functions and uses of archival images and testimony in audiovisual productions about Mozambican-Portuguese decolonization. Funding for his research was provided by Gerda Henkel Stiftung. Simultaneously, he is involved in a research project about media and participation at the University of Konstanz.

Contact: Institut für Medienwissenschaft, Fachbereich Literaturwissenschaft, Universität Konstanz, Fach 157, 78457 Konstanz, Germany.

E-mail: robert.stock@uni-konstanz.de

Robert Stock has asserted his right under the Copyright, Designs and Patents Act, 1988, to be identified as the author of this work in the format that was submitted to Intellect Ltd. 